\title{
Population dynamics and life history of the rare arctic- alpine plant Sagina nivalis (Caryophyllaceae) on the Ben Lawers range, Scotland, UK
}

\author{
David K. Mardon; Sarah H. Watts* \\ The National Trust for Scotland, Edinburgh, Scotland, UK. \\ *Corresponding author: Sarah H. Watts, email: shwatts@nts.org.uk
}

This pdf constitutes the Version of Record published on $11^{\text {th }}$ February 2019.

\begin{abstract}
The flora of Scotland's mountains is of international significance as it contains arcticalpine species at the edge of their global range. Such rear edge populations deserve high priority investigation due to their unique local adaptations, important conservation value and because montane plants may be particularly sensitive to environmental change. Sagina nivalis is one of the rarest and least known arcticalpines in Britain and the vast majority of plants occur within the Ben Lawers SSSI. Ten permanent plots were surveyed here from 1982-1994 by counting the number of plants and tagging and measuring individuals throughout the duration of their lives. The total number of plants present at each colony across the whole site was also recorded in 1996 and 2014. Extreme fluctuations in numbers occurred within periods of very few years and were associated with the fragile and dynamic nature of the montane habitat. Seedling mortality was very high, but age had no effect on survival rates once plants were one year old. Most were small, only lived two years and produced none or few flowers, although those that survived long enough generally reached their maximum size and flowering potential when they were five years old. The number of plants present across the whole of Ben Lawers halved between 1996 and 2014, with half of all colonies extinct and a further third in significant decline. The greatest threats to $S$. nivalis in Scotland were identified as habitat damage due to natural processes, sheep activity and climate change. A reduction in snow cover may cause an interaction between these factors and compromise the long-term survival of rear edge populations of this species, other rare arctic-alpines in Scotland and their associated contribution to biodiversity.
\end{abstract}

Key words: Snow pearlwort; conservation; demography; longevity; threats; climate change

\section{Introduction}

Populations located at the low-latitude margins of a species' distribution (rear edge) are of important conservation value because they can be rich in genetic diversity, exhibit distinct local adaptations and contain unique ecotypes (Hampe \& Petit, 2005; Rehm et al., 2015). Rear edge populations therefore deserve high priority for investigation in order to preserve the evolutionary potential of the species and maintain biodiversity through anticipated global change (Provan \& Maggs, 2011), yet such ecological research is currently limited (Hampe \& Petit, 2005). 
The arctic-alpine flora of Scotland's mountains is of international significance as it contains many rare species at the rear edge of their global range (Sydes, 2008). Montane plants may be sensitive to environmental change because they are often intolerant of competition and heavy grazing, are specifically adapted to low temperatures and exist in fragile and dynamic habitats (Milne \& Hartley, 2001; Björk $\&$ Molau, 2007). Populations that are small and isolated are particularly at risk (Sydes, 2008).

The conservation management of vulnerable species requires a considerable knowledge of existing populations and the factors affecting them over the short and long-term, as well as an understanding of important aspects of their life histories such as longevity, survival rates and fecundity. The most effective population studies are those that use permanently marked plots over decadal timescales (Geddes \& Miller, 2010; Ross, 2015) but the remote location of montane species usually precludes such work. Detailed life history information has been recorded for very few of Scotland's threatened plants (Legg et al., 1997), and empirical data on survival and life span is lacking for plants in general (Lauenroth \& Adler, 2008), particularly arctic-alpines (Morris \& Doak, 1998).

The snow pearlwort, Sagina nivalis (Lindblom) Fr., is one of Britain's rarest and least known arctic-alpine plants (Wigginton, 1999). It is a dwarf, tufted cushionforming perennial with tiny white flowers which open only on sunny days between July and September, and are automatically self-pollinated (Clapham et al., 1962). Because of the plant's inconspicuous growth form, it can be found only by careful observation, and often eludes even skilled botanists. Images in Plate 1 are provided at higher resolution in supplementary files Image 1 - Image5 in TIFF format.

The species has a predominantly arctic and sub-arctic circumpolar distribution in the Northern Hemisphere but has also been reported from the western Alps (Benum, 1958; Clapham et al., 1962). The Scottish populations are at the extreme southern margin of its north European range and are confined to a few mountains in the Breadalbane region of the Central Highlands. This restricted British distribution currently appears to be associated with a combination of environmental factors: high altitude, calcareous mica-schist bedrock and a low maximum temperature (Evans, 1982). The vast majority of known locations are within the Ben Lawers Site of Special Scientific Interest (SSSI) at altitudes between 915 and $1192 \mathrm{~m}$. Records of $S$. nivalis were few prior to the 1980s when the species was found to be no longer present on the summit rocks on Ben Lawers (Raven \& Walters, 1956), and by 1981, it had disappeared from two of the three sites recorded in 1980 (D.K. Mardon, personal observation). Concerns were expressed for its vulnerability for local extinction. Fortunately, a comprehensive survey in 1981 found enough colonies and a sufficient number of plants to discount the possibility that the species was currently endangered (Payne, 1981). However, the Ben Lawers SSSI is subject to serious pressures from grazing animals and recreational use, and casual observations of the plant's habitat suggested that it was particularly vulnerable to disturbance.

This paper describes the results of a long-term study to monitor the population dynamics, turnover rate and life history of $S$. nivalis with the aim of identifying potential threats to the conservation of this arctic-alpine at its rear edge in Scotland. Specifically, data gathered from ten permanent plots on the Ben Lawers range between 1982 and 1994 were used to address the following questions:

1. How did the number of plants in the plots change during the study period and what factors were responsible for any fluctuations? 
2. What is the lifespan of the species and how did this vary between the study plots?

3. How did plant survival vary with age?

4. What was the size range of the plants and how did this vary with age?

5. How was flowering affected by the age and size of the plants?

\section{Materials and methods}

Plant nomenclature follows Stace (2010).

\section{Study site}

The Ben Lawers National Nature Reserve (NNR) as currently designated is owned and managed by the National Trust for Scotland (NTS). The more extensive Site of
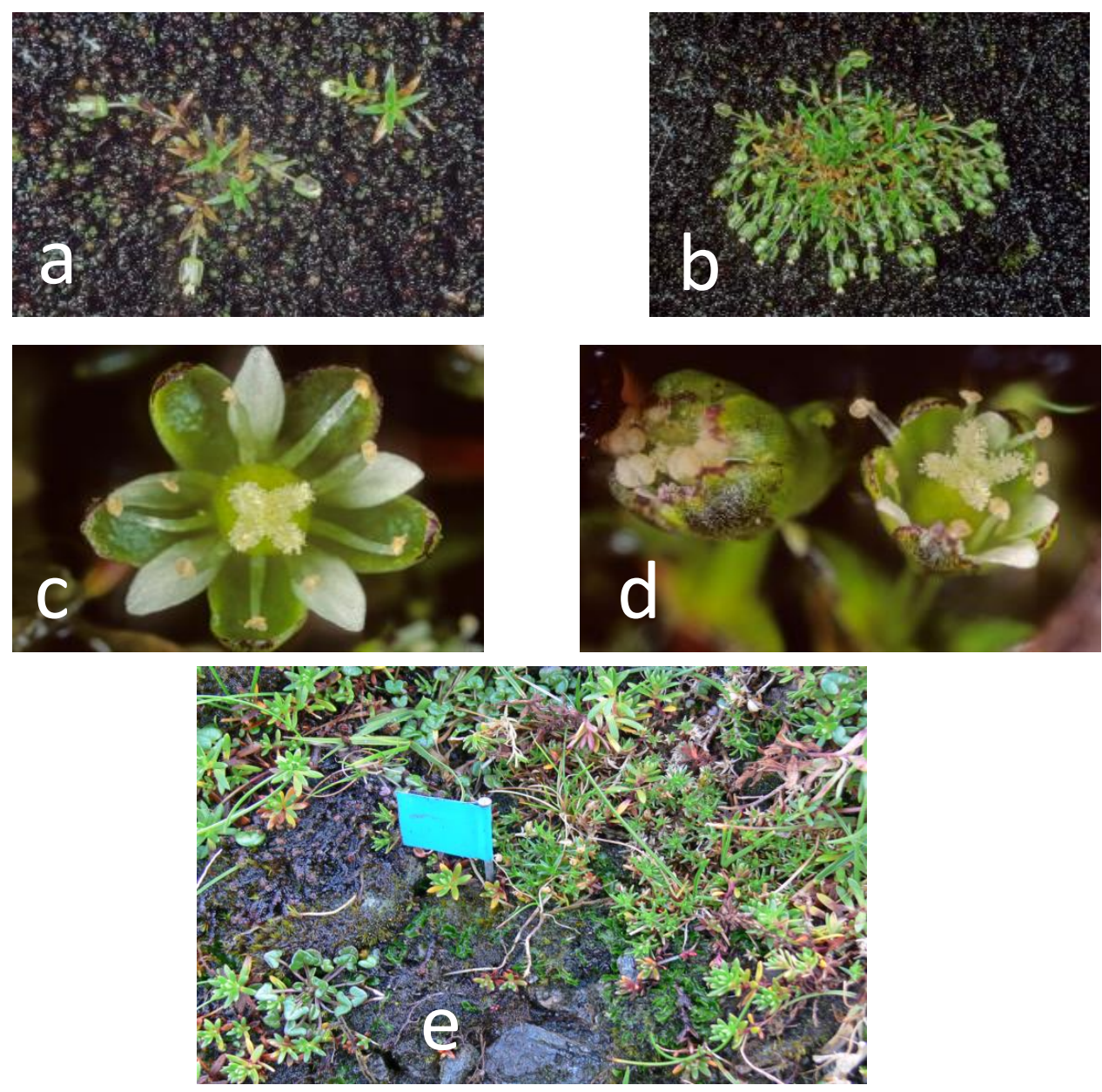

Plate 1 (a) Medium flowering Sagina nivalis plant (longest diameter in the range 13-25mm) and small flowering plant (longest diameter less than $13 \mathrm{~mm}$ ); (b) Mature large flowering plant (longest diameter at least

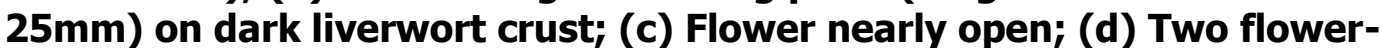
buds opening; (e) Non-flowering plant of medium size (longest diameter $13-25 \mathrm{~mm})$ next to the blue flag (20mm across). This photo illustrates the difficulty of finding $S$. nivalis within its habitat. particularly when growing amongst Minuartia sedoides. 
Special Scientific Interest (SSSI) encompasses a nine-mile stretch of nine mountains including the $10^{\text {th }}$ highest in Britain. The geology of the SSSI includes soft Dalradian calcareous mica schists which give rise to basic soils. It is arguably the most important site in Britain for montane plants and has been designated also as a Special Area of Conservation and a National Scenic Area. In addition to S. nivalis it supports populations of around 16 other nationally rare vascular plant species (Wigginton, 1999), as well as a significant number of rare bryophytes and lichens.

Sagina nivalis study plots (1981-1994)

Ten permanent study plots for $S$. nivalis were established in 1981 across four mountains within the Ben Lawers SSSI (Beinn Ghlas, Ben Lawers, An Stuc and Meall Garbh). Observations that year showed that the plant typically grows on a surface mat of bryophytes over a substrate of calcareous gravels, both on ground subject to frequent flushing and on drier rock ledges. The sites were therefore chosen to encompass this habitat variation, at altitudes of between $970-1160 \mathrm{~m}$, and on range of slope angles and aspects, while also allowing field observations to be completed in a minimum amount of time, estimated at two or three days annually. The Ben Lawers range is grazed by sheep from adjacent farms, some with heritable grazing rights on the NTS land. Deer also use the area but were never observed on or near the study sites during the project or on numerous visits since. Numbers of sheep also far exceed those of deer. Plots 1, 2 and 3 were inaccessible to sheep grazing, but are sometimes affected by rockfalls caused by sheep. Other species commonly found in the plots included Cochlearia micacea, Sagina saginoides, Salix herbacea and Saxifraga oppositifolia. In the wet flushes the moss Blindia acuta was almost invariably present, frequently with the higher plant associates Juncus trig/umis, Saxifraga stellaris, and often Juncus big/umis. On the drier sites S. nivalis was accompanied by Alchemilla alpina, Festuca vivipara, Minuartia sedoides, Silene acaulis, and sometimes Saxifraga nivalis.

A study plot of approximately $1 / 4 \mathrm{~m}^{2}$ was chosen because of the diminutive form of the species (described below). This size was roughly the extent of many colonies, was convenient for fitting onto the ledges where they occurred and was the optimal dimensions for producing a useful photographic record. The corners were marked by wooden pegs of c. $20 \mathrm{~mm}$ square section inserted to ground level and topped with a wire nail for attaching string to define the plot's boundary. Plot shape varied with the feasibility of placing 'permanent' markers, and with the terrain, and was roughly square, rectangular, trapezoidal or triangular. Permanence could not be assured, due to the dynamic nature of the habitats. It was therefore advantageous to visit certain sites each spring to reposition marker pegs dislodged by frost heave and note any other evidence of disturbance during the winter. All markers were removed at the end of the study.

The study plots were visited annually in August or very soon after, from 19821994 , to record the number of plants present. Initially, each individual was marked by a temporary tag as an aid to counting. Searching for the small and often inconspicuous pearlworts was slow and time-consuming, and plants, once spotted, could easily be overlooked when counting. The tags overcame this difficulty by separating the search and find operation from the counting and recording, thus enhancing the accuracy of the results. Each tag was a "flag" of plastic adhesive tape on a $40 \mathrm{~mm}$ zinc-coated panel pin. Such a marker caused negligible habitat damage and was an optimal size for photographic recording. Two colours were used, red and yellow, cut into three different shapes to distinguish six categories as follows: 
1. Large flowering - longest diameter at least c.25 mm;

2. Medium flowering - longest diameter in the range $13-25 \mathrm{~mm}$;

3. Small flowering - longest diameter less than $13 \mathrm{~mm}$;

4. Non flowering - generally small; size not categorised;

5. Seedling - minute, usually with only one pair of leaves (cotyledons), sometimes with a second pair, but with the potential for misidentification, often growing in dense clusters. Assumed to be $<1$ year old, germinated in the current season. If developed enough for confident identification, some isolated seedlings could be tagged, but an overall count was not realistic.

6. Dead, dying - helped to account for plants that had died since the last visit. Some such remains were recognisable more than a year after death.

A photographic record of the plots each year assisted the relocation of plants on subsequent visits and provided a gross visual indication of changes in the distribution of individuals and structure of a colony, including destructive events that directly affected the population. The photographs were on $35 \mathrm{~mm}$ colour negative film, to facilitate printing in the days of only analogue photography. Field notes also included any other relevant information, for example signs of disturbance such as hoof prints or landslip.

During the years 1983-1993 life history information was also recorded at eight of the plots, as follows:

1. the location of each individual plant, defined by its distance from the two lowest, i.e. nearest, corner pegs, measured to the nearest $5 \mathrm{~mm}$;

2. its overall size, measured as the product of the greatest diameter and that at $90^{\circ}$;

3. the number of flowers, counted with the aid of a seeker (a small metal probe, $1 \mathrm{~mm}$ thick, angled and mounted on a handle, for biological use). Any seed capsules already present were also counted as (former) flowers.

Collecting this amount of data annually from Plots 2 and 10 proved impractical because of the large number of plants (in 1983), which took an excessive time to record, and entailed errors in recognising individuals. Also, the precarious position of Plot 2 posed greater personal risk than other sites. Size and flowering measurements were taken for flowering plants in Plot 10 only in 1983 and 1985.

The number of flowers (or capsules) counted on the plants during a single visit to the study plots was assumed to be the total produced by each individual over the course of the whole season. While it is possible that some flowers were missed, this possible error was minimised by ensuring that monitoring took place once the peak of flowering had occurred, which early observations suggested was in August.

The coordinates were recorded or re-recorded so that the progress of each individual could be tracked throughout the study. However, data from the first three years showed that the positions of plants changed from year to year, presumably due to shifting of the surface crust, or of the marker pegs, with frost heave. Also, the 'centre' of a plant would appear to move by asymmetrical growth from the stock: the basal rosette is not distinguishable in mature plants. Since 1986 therefore, to aid recognition of individual plants, they were also 'permanently' tagged with coloured haberdashery pins, although these too became dislodged in some cases. 
Some adult plants seemed to appear spontaneously and presumably had been overlooked or not recorded as seedlings. The vast majority of these were small and non-flowering and so they were classed as 1-year olds.

Although life history data were not collected in 1982 or 1994, it was possible to gain additional information about the age of some plants using the photographs. An individual that first appeared as a seedling or an adult in 1983 could have its lifespan measured. Any adult plant present in an identical location in the 1982 and 1983 photographs was assumed to be the same individual. It was not possible to determine age and lifespan in this case because the plant may have been alive before the study began. Any plant present in 1993 that disappeared from the 1994 photograph was assumed to have died. Lifespan could not be recorded for individuals still alive in 1994.

\section{Full population surveys (1996 \& 2014)}

The total number of plants present at each of the 37 S. nivalis colonies found on the Ben Lawers range during the original 1981 survey was counted during subsequent visits in 1996 and 2014 (MacGregor, 1996; Watts, 2014). The status of each colony was assessed in 2014 as being either:

1. Extinct; no plants found

2. Declining (a loss of $\geq 30 \%$ of plants present in 1996)

3. Stable (no significant change in plant numbers since 1996)

4. Increasing (an increase of $\geq 30 \%$ of plants present in 1996)

\section{Data analysis}

We marked 437 seedlings with temporary tags, but many more would have been missed using the method detailed (as explained above). The seedling stage was therefore not included in the data analysis, and the results apply to plants that reached at least one year of age. A life table of survival and mortality was constructed using the calculations described in Begon et. al. (1996), except that the fecundity schedule (the last two columns of Table 2) relates to the number of flowers produced rather than the actual number of offspring produced. Each consecutive year of life was defined as a separate age class.

The variation in plant lifespan between the study plots was tested using Analysis-of-variance (ANOVA). Normal distribution of the original data and the residuals was confirmed using the Kolmogorov-Smirnov test and histograms. Equal variance was determined using Levene's test. A post hoc Tukey's multiple comparison test was used to identify which plots differed significantly from each other at the $95 \%$ confidence level. Variation in the diameter of the plants with age was tested using a repeated measures General Linear Model. The data were log transformed and combined for 8 and 9-year old plants due to the small sample size in these categories.

Plant area was calculated by multiplying the diameter (greatest distance measured across the plants) by the width at $90^{\circ}$ to the longest width. The resulting figure, however, overestimates the total area, as the cushions are not rectangular and the foliage can vary in density. The relationship between plant area and number of flowers was tested using linear regression. This included a small number of plants measured in Plot 10 in 1983 and 1985. Plants still alive at the end of the study excluded from the analyses of lifespan and maximum size. Plants already present before the study began were only included in the analysis involving the relationship between the number of flowers and plant size. 


\section{Results}

\section{Population dynamics}

Fig. 1 shows the population dynamics observed in the ten study plots. Fig. 1a gives the data for the two plots with the highest densities of $S$. nivalis (Plots 2 and 10), which follow very similar curves, the result of two different causes, described below. In Figs $1 \mathrm{~b}-\mathrm{d}$ plots are grouped according to some physical changes that affected the habitat (overgrowth of vegetation, disturbance caused by sheep or flooding).

The numbers of individuals recorded at different sites ranged from 0 to 180 , with both extremes recorded on Plot 10. All locations showed marked fluctuations, sometimes doubling, trebling or even quadrupling, or crashing, between consecutive years (i.e. the interval between annual visits). These peaks and troughs did not coincide between plots; however, the overall pattern of change was a rapid increase followed by a slower, progressive and serious decrease (Fig. 2). This trend was the result of the high abundance of $S$. nivalis in Plots 2 and 10 (Fig. 1a), which included two-thirds of the plants recorded at the overall peak in 1985. These data illustrate the difficulty that would apply to any attempt to use samples of the overall population to measure trends. Nevertheless, most sites were in decline over the later years of the project.

Table 1 summarises the overall trends and most important events which took place at each study plot. Selected photographic examples are provided in Plate 2.
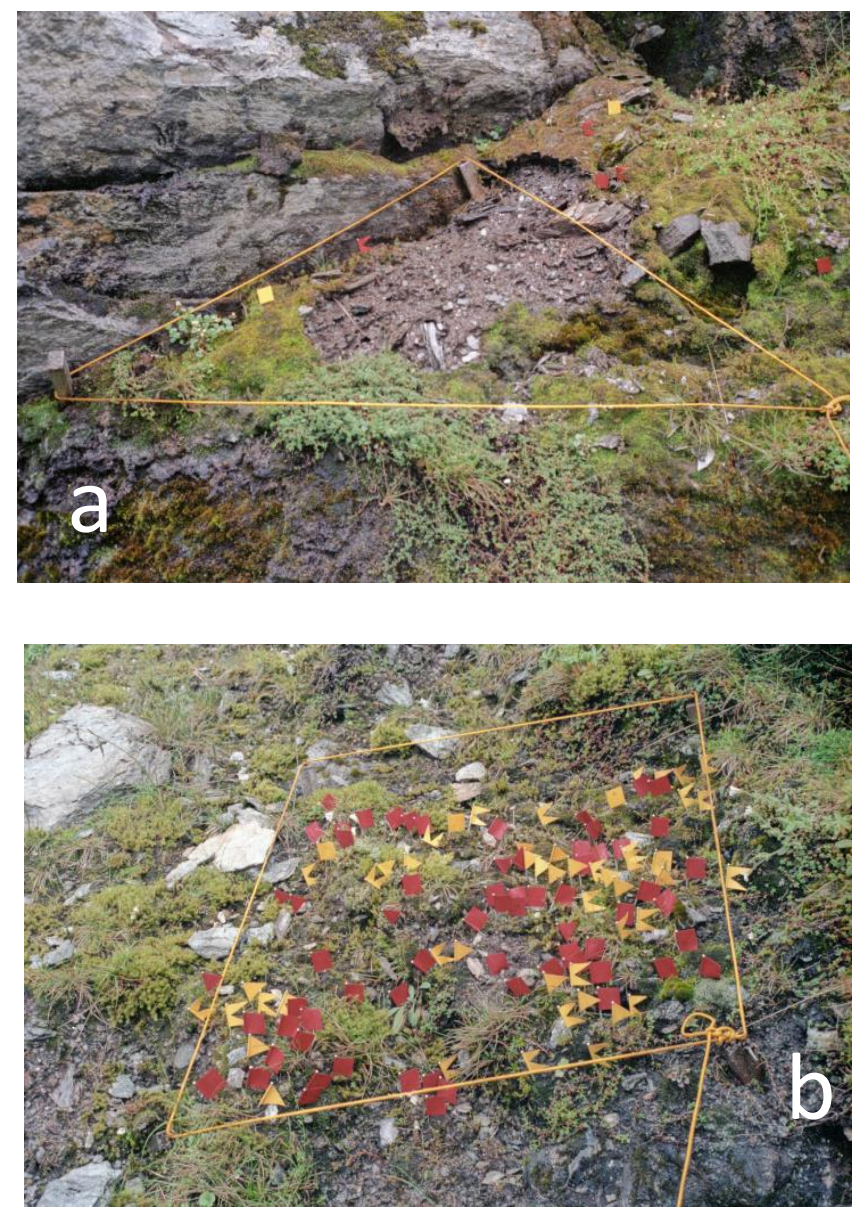

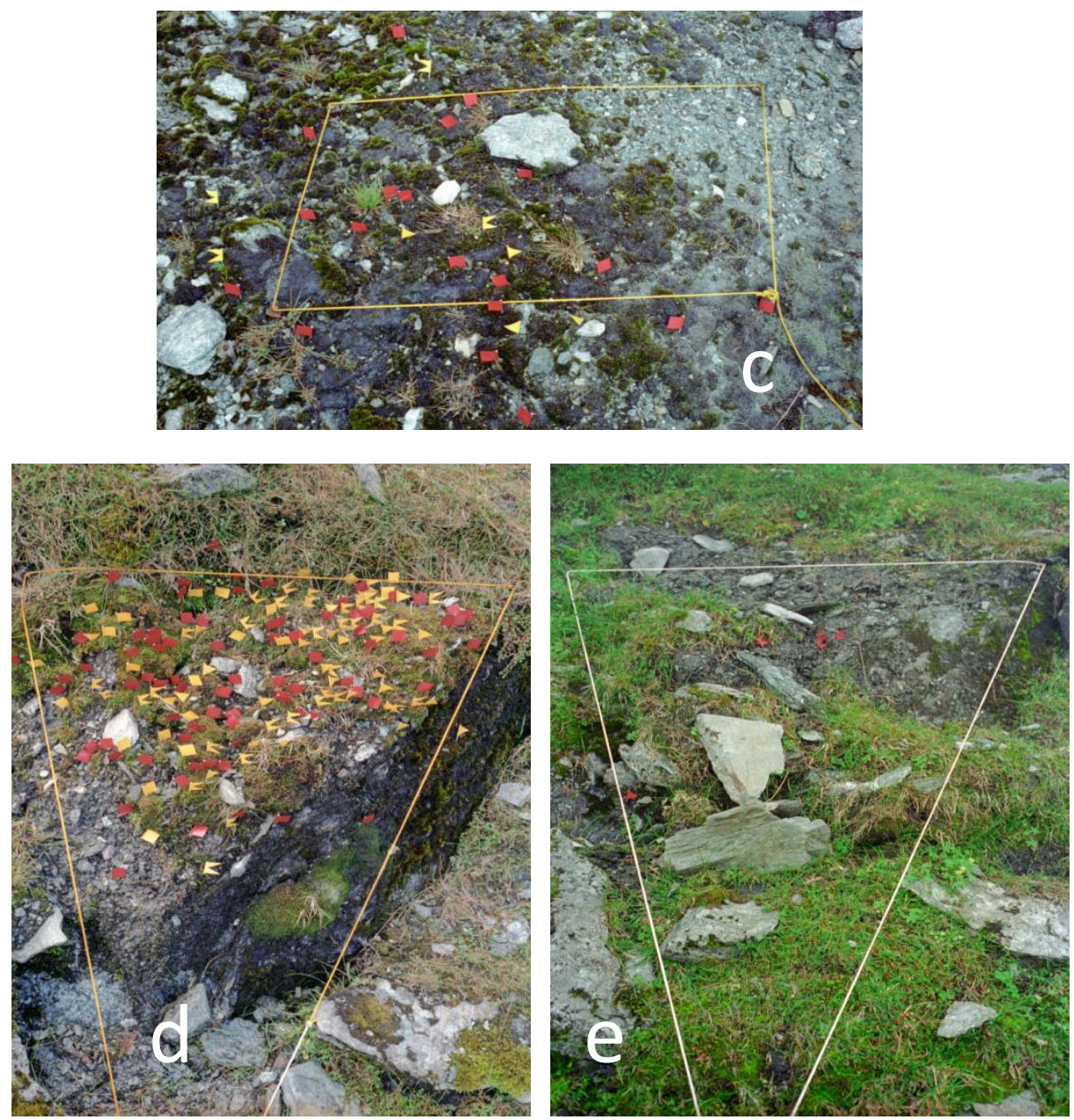

Plate 2 Photographs of selected plots to show important events during the study. Flags denote the location of individual $S$. nivalis plants, split into different shapes to distinguish categories as follows: Yellow square: Large flowering (longest diameter at least c.25 mm); Yellow cut out triangle: Medium flowering (longest diameter in the range 13-25 mm); Yellow triangle: Small flowering (longest diameter less than $13 \mathbf{~ m m}$ ); Red square: Non-flowering (generally small; size not categorised); Red cut out triangle: Seedling (minute, usually with only one pair of leaves); Red triangle: Dead, dying. (a) Plot 1 (a near vertical face) in 1985 after a major landslip event; (b) Plot 2 at its maximum population size in 1985; (c) Plot 7 in 1991 showing wetter Sagina nivalis habitat; (d) Plot 10 in 1985; and (e) in 1994 after sheep trampling, landslip, rockfall and vegetation encroachment sianificantlv altered the habitat.

The annual observation usually revealed unequivocally the cause of the extreme or rapid population changes shown by Fig. 1. Five plots were subjected to erosion by landslip events, four plots were trampled by sheep and two plots were affected by flooding. If monitoring were on a longer cycle, say six-yearly, such explanation could be missed. Vegetation encroachment occurred towards the end of the study in all plots except Plot 1. 

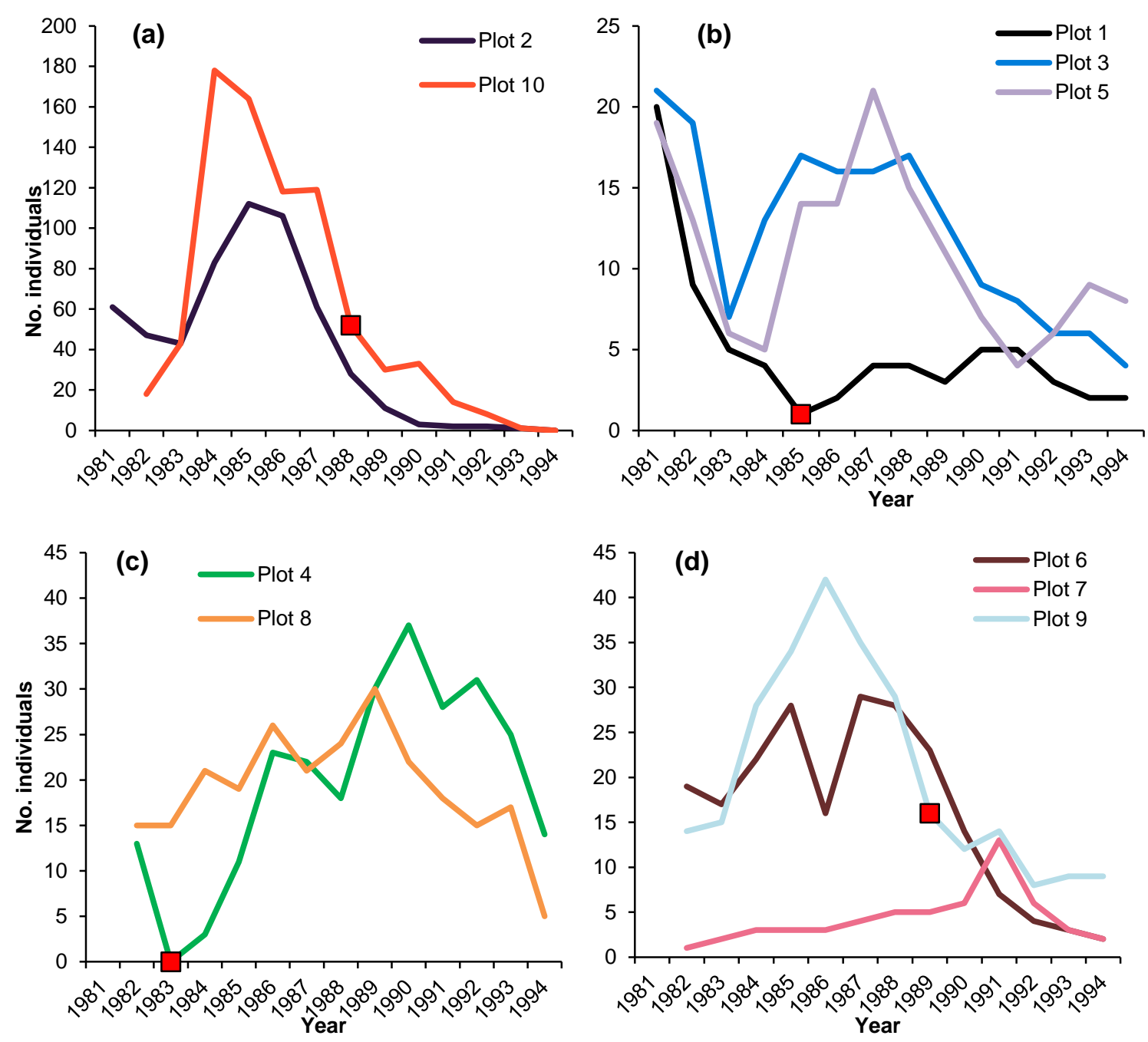

Figure 1. The number of individuals of Sagina nivalis recorded on each study plot between 1981 and 1994, grouped by similarity of habitat history: (a) plots with high density of Sagina nivalis, b) minor vegetation encroachment; (c) significant vegetation encroachment; (d) major disturbance caused by sheep or flooding. Major landslip events are annotated by squares. Note the different scale for Fig. 1a (Plots 2 and 10).

Table 1. A description of the habitat at each of the monitoring plots and the most important events which affected them between 1981 and 1994. The number of plants present at the beginning and end of the study is also given, along with the maximum and minimum recorded and the overall trend

\begin{tabular}{|l|l|l|l|l|l|l|l|}
\hline Plot & Description & $\mathbf{1 9 8 1 / 2}$ & $\mathbf{1 9 9 4}$ & Max. & Min. & $\begin{array}{l}\text { Overall } \\
\text { trend }\end{array}$ & Habitat changes \\
\hline 1 & $\begin{array}{l}\text { On near vertical } \\
\text { face with } \\
\text { bryophyte crust. }\end{array}$ & 20 & 2 & $\begin{array}{l}20 \\
(1981)\end{array}$ & $\begin{array}{l}1 \\
(1985)\end{array}$ & $\begin{array}{l}\text { Rapid } \\
\text { decline to } \\
\text { 1985, stable } \\
\text { thereafter at } \\
\text { low numbers }\end{array}$ & $\begin{array}{l}\text { Crust sloughed off } \\
\text { with loss of plants } \\
\text { in 1984-5. }\end{array}$ \\
\hline 2 & $\begin{array}{l}\text { On sloping shelf } \\
\text { within large cliff } \\
\text { area. }\end{array}$ & 61 & 0 & $\begin{array}{l}112 \\
(1985)\end{array}$ & $\begin{array}{l}0 \\
(1994)\end{array}$ & $\begin{array}{l}\text { Increase to } \\
1985, \\
\text { followed by } \\
\text { progressive } \\
\text { decline }\end{array}$ & $\begin{array}{l}\text { Soil slippage in } \\
\text { 1989-90, then the } \\
\text { vegetation closed } \\
\text { over the site, } \\
\text { including some } \\
\text { robust mosses. }\end{array}$ \\
\hline
\end{tabular}




\begin{tabular}{|c|c|c|c|c|c|c|c|}
\hline 3 & $\begin{array}{l}\text { On near vertical } \\
\text { rock face with } \\
\text { bryophytes in } \\
\text { cracks. }\end{array}$ & 21 & 4 & $\begin{array}{l}21 \\
(1981)\end{array}$ & $\begin{array}{l}4 \\
(1994)\end{array}$ & $\begin{array}{l}\text { Fluctuating } \\
\text { towards a } \\
\text { decline }\end{array}$ & $\begin{array}{l}\text { Little noticeable } \\
\text { change, only slight } \\
\text { encroachment of } \\
\text { vegetation. }\end{array}$ \\
\hline 4 & $\begin{array}{l}\text { On sloping } \\
\text { vegetated ledge } \\
\text { below rock face. }\end{array}$ & 13 & 14 & $\begin{array}{l}37 \\
(1990)\end{array}$ & $\begin{array}{l}0 \\
(1983)\end{array}$ & $\begin{array}{l}\text { Increase to } \\
1990, \\
\text { decline } \\
\text { thereafter. }\end{array}$ & $\begin{array}{l}\text { Plot buried with } \\
\text { soil slipped from } \\
\text { above in 1982-3; } \\
\text { all plants in plot } \\
\text { covered, but some } \\
\text { present adjacent to } \\
\text { and above plot. } \\
\text { Vegetation } \\
\text { encroachment } \\
\text { from } 1990 .\end{array}$ \\
\hline 5 & $\begin{array}{l}\text { On bryophyte } \\
\text { crust surrounded } \\
\text { by vascular plant } \\
\text { cover; near } \\
\text { horizontal. }\end{array}$ & 19 & 8 & $\begin{array}{l}21 \\
(1987)\end{array}$ & $\begin{array}{l}4 \\
(1991)\end{array}$ & $\begin{array}{l}\text { Increase to } \\
1987, \\
\text { decline } \\
\text { thereafter. }\end{array}$ & $\begin{array}{l}\text { Plot stable, with no } \\
\text { marked changes. } \\
\text { Slight sheep } \\
\text { trampling } 1988 \\
\text { and } 1991 ; \text { slight } \\
\text { erosion and } \\
\text { encroachment of } \\
\text { vascular plants } \\
\text { 1992-3. }\end{array}$ \\
\hline 6 & $\begin{array}{l}\text { On shelf below } \\
\text { small cliff; near } \\
\text { horizontal. }\end{array}$ & 19 & 2 & $\begin{array}{l}29 \\
(1987)\end{array}$ & $\begin{array}{l}2 \\
(1994)\end{array}$ & $\begin{array}{l}\text { Fluctuating, } \\
\text { then decline } \\
\text { after } 1987 .\end{array}$ & $\begin{array}{l}\text { Recurring sheep } \\
\text { trampling, } \\
\text { especially 1987, } \\
1989 \text { and } 1991 \\
\text { onwards, also } \\
\text { some } \\
\text { encroachment of } \\
\text { vegetation. }\end{array}$ \\
\hline 7 & $\begin{array}{l}\text { On bryophyte } \\
\text { crust in wet area } \\
\text { adjacent to small } \\
\text { burn. }\end{array}$ & 1 & 2 & $\begin{array}{l}13 \\
(1991)\end{array}$ & $1(1982)$ & $\begin{array}{l}\text { Increase to } \\
1991, \\
\text { decline } \\
\text { thereafter. }\end{array}$ & $\begin{array}{l}\text { Subject to frost } \\
\text { heave and water } \\
\text { damage 1988-9; } \\
\text { some } \\
\text { encroachment of } \\
\text { graminoids } \\
\text { progressively } \\
\text { 1988-94. }\end{array}$ \\
\hline 8 & $\begin{array}{l}\text { In area with little } \\
\text { vascular plant } \\
\text { cover, subject to } \\
\text { flooding. }\end{array}$ & 15 & 5 & $\begin{array}{l}30 \\
(1989)\end{array}$ & $5(1994)$ & $\begin{array}{l}\text { Increase to } \\
1989, \\
\text { decline } \\
\text { thereafter }\end{array}$ & $\begin{array}{l}\text { Graminoid cover } \\
\text { increased } \\
\text { progressively } \\
\text { across plot 1982- } \\
\text { 94; flooding and } \\
\text { silt deposition, } \\
\text { especially 1986-87. }\end{array}$ \\
\hline 9 & $\begin{array}{l}\text { Within wet flush } \\
\text { system, on a soft, } \\
\text { vulnerable } \\
\text { substrate. }\end{array}$ & 14 & 9 & $\begin{array}{l}42 \\
(1986)\end{array}$ & $\begin{array}{l}8 \\
(1992)\end{array}$ & $\begin{array}{l}\text { Increase to } \\
1986, \\
\text { decline } \\
\text { thereafter }\end{array}$ & $\begin{array}{l}\text { Frequent sheep } \\
\text { trampling, with } \\
\text { severe, destructive } \\
\text { effect on some } \\
\text { plants; some } \\
\text { progressive } \\
\text { graminoid } \\
\text { encroachment, } \\
\text { especially 1988-94. }\end{array}$ \\
\hline 10 & $\begin{array}{l}\text { On sloping rock } \\
\text { with mostly } \\
\text { bryophyte cover; } \\
\text { with bare soil }\end{array}$ & 18 & 0 & $\begin{array}{l}178 \\
(1984)\end{array}$ & $\begin{array}{l}0 \\
(1994)\end{array}$ & $\begin{array}{l}\text { Rapid } \\
\text { increase to } \\
1984, \\
\text { followed by }\end{array}$ & $\begin{array}{l}\text { Crust broken up by } \\
\text { sheep hooves \& } \\
\text { sloughed off } \\
\text { downwards }\end{array}$ \\
\hline
\end{tabular}




\begin{tabular}{|l|l|l|l|l|l|}
\hline $\begin{array}{l}\text { visible from 1982, } \\
\text { most stable 1984- } \\
5 .\end{array}$ & & & & $\begin{array}{l}\text { progressive } \\
\text { decline }\end{array}$ & $\begin{array}{l}\text { progressively, } \\
\text { especially from } \\
\text { 1987-8. Rocks } \\
\text { encroached from } \\
\text { above and } \\
\text { graminoid and forb } \\
\text { cover increased. }\end{array}$ \\
\hline
\end{tabular}

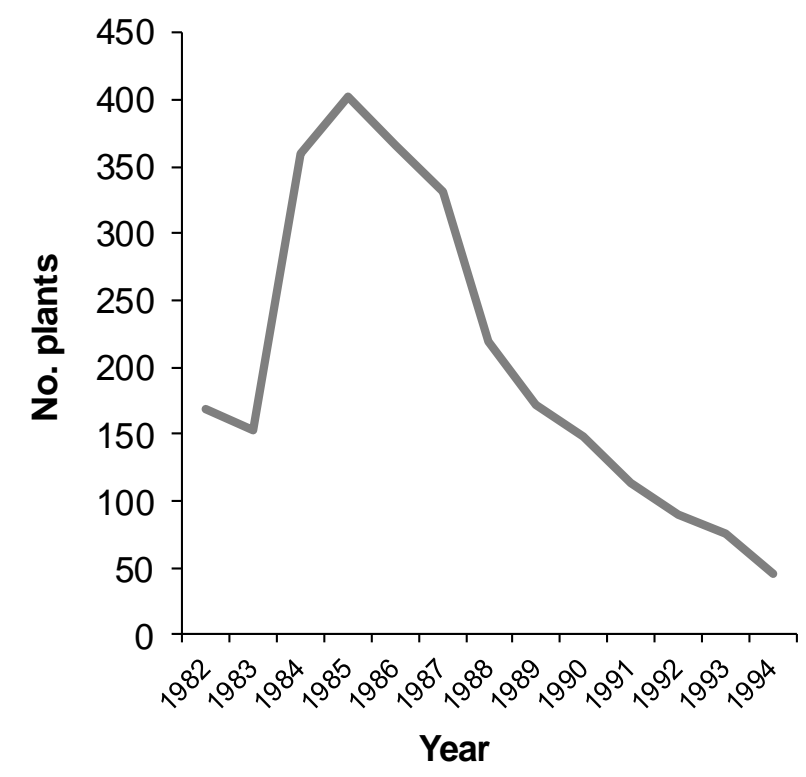

Figure 2. Summary of population changes for Sagina nivalis on each the 10 study plots (all study plots amalgamated).

\section{Life History}

The data used for this part of the study were recorded from only eight plots, excluding Plots 2 and 10, where the greater number of plants, and their higher density, precluded the repeated recognition of individual plants.

\section{Lifespan}

The mean lifespan of $S$. nivalis during the study was 2.37 years ( \pm 1 SE $0.08, n=$ 458) although some plants did survive up to 9 years of age (Fig. 3). The plants in Plots 1 and 3 had a significantly longer lifespan than those at all other sites except Plot 5. $\left(F_{7,450}=6.85, \mathrm{p}<0.001\right)$ (Fig. 3).

\section{Survival}

The life table (Table 2 ) shows that the survival rate $\left(I_{x}\right)$ decreased substantially as the plants got older. However the age specific mortality rate $\left(q_{x}\right)$ was highest for seedlings and lowest for plants of 3 years of age, after which there was only a slight increasing trend until the plants reached 9 years. In fact, the survivorship (Fig. 4) displays a classic Deevey Type II curve with constant mortality. Individuals therefore experienced a constant chance of surviving from one age to the next throughout their lives once they passed the seedling stage. 


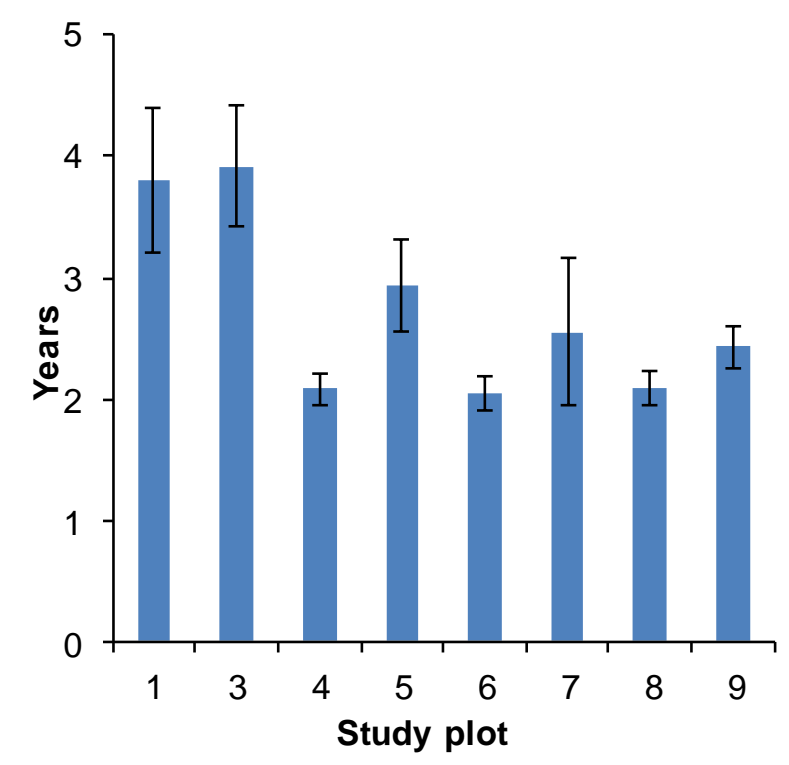

Figure 3. Mean lifespan of Sagina nivalis at each study plot (for plants that survived past the seedling stage). The error bars are 1 standard error.

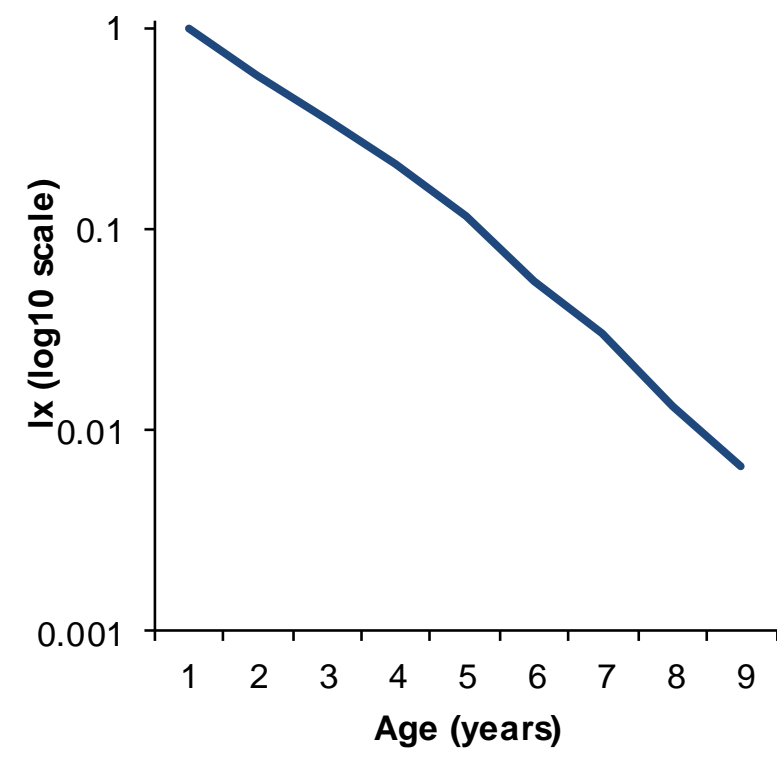

Figure 4. Survivorship curve for Sagina nivalis, with each consecutive year of life defined as a separate age class. $I_{x}$ is the survival rate.

Size

The mean maximum diameter obtained by individuals of $S$. nivalis over the duration of their lifetime was $13.94 \mathrm{~mm}( \pm 1 \mathrm{SE} 0.45, n=426)$ but measurements as large as $55 \mathrm{~mm}$ were recorded. $62.4 \%$ of plants grew to no more than $12.5 \mathrm{~mm}$ in diameter, while only $12.4 \%$ of plants grew to over $25 \mathrm{~mm}$. Leaf size was normally up to $7 \mathrm{~mm}$, rarely to $12 \mathrm{~mm}$. Mean maximum diameter could therefore be achieved with very few leaves.

The mean maximum area that individuals of $S$. nivalis grew to was $2.01 \mathrm{~cm}^{2}$ ( \pm 1SE $0.14, n=426)$. Although areas of up to $24.75 \mathrm{~cm}^{2}$ were recorded, $33 \%$ and $50 \%$ of all plants never grew to more than $0.5 \mathrm{~cm}^{2}$ and $1 \mathrm{~cm}^{2}$ respectively. Only $3 \%$ ever reached more than $10 \mathrm{~cm}^{2}$. 
Table 2. Life table for the Sagina nivalis monitored from 1982-1994 for plants that survived past the seedling stage. $a_{x}=$ number that survived to the start of each age class; $I_{x}$ (survival rate) $=$ the proportion of plants from the first age class (one year-olds) that survived to the start of each age class; $d_{x}=$ the proportion of plants from the first age class that died during each age class; $q_{x}$ (age specific mortality rate) $=$ the fraction of the population that died during each age class, calculated by $d_{x} / I_{x i} m_{x}=$ the mean number of flowers produced per surviving individual in each age class; $I_{x} m_{x}=$ the mean number of flowers produced per original individual from the first age class. * calculated from the 437 plants that were tagged as seedlings.

\begin{tabular}{|c|c|c|c|c|c|c|}
\hline $\begin{array}{c}\text { Age class, } \\
x \text { (years) }\end{array}$ & $a_{x}$ & $I_{x}$ & $d_{x}$ & $q_{x}$ & $m_{x}$ & $I_{x} m_{x}$ \\
\hline Seedling & & & & $0.66^{*}$ & & \\
\hline 1 & 458 & 1 & 0.42 & 0.42 & 0.27 & 0.27 \\
\hline 2 & 267 & 0.58 & 0.23 & 0.40 & 1.48 & 0.86 \\
\hline 3 & 160 & 0.35 & 0.14 & 0.39 & 3.32 & 1.16 \\
\hline 4 & 98 & 0.21 & 0.098 & 0.46 & 3.92 & 0.84 \\
\hline 5 & 53 & 0.12 & 0.061 & 0.53 & 5.71 & 0.66 \\
\hline 6 & 25 & 0.055 & 0.024 & 0.44 & 3.79 & 0.21 \\
\hline 7 & 14 & 0.031 & 0.017 & 0.57 & 4.76 & 0.15 \\
\hline 8 & 6 & 0.013 & 0.0066 & 0.50 & 3.17 & 0.04 \\
\hline 9 & 3 & 0.0066 & 0.0066 & 1 & 1.00 & 0.007 \\
\hline & & & & & & Total: 4.19 \\
\hline
\end{tabular}

Plant diameter varied significantly with age $\left(F_{7,624}=32.58, p<0.001\right)$. Oneyear old plants had a mean diameter of $9.07 \mathrm{~mm}( \pm 1$ SE $0.24, n=422)$ which increased each year until they reached $19.47 \mathrm{~mm}( \pm 1 \mathrm{SE} 1.44, n=59)$ at 5 years old. Plants that survived longer than this tended not to grow any further, and very old plants were observed dying back in their last year of life. 8 and 9-year olds had a mean diameter of $14.78 \mathrm{~mm}$ ( \pm 1 SE $2.67, n=9$ ).

\section{Flowering}

On average plants produced a mean of 4 flowers throughout the entire duration of their lifespan, with the most important age classes for flowering being 2-5 years (Table 2 ). $57.5 \%$ of plants never grew any flowers at all before they died but a small proportion (4.7\%) did generate at least 25 flowers over their lifetime. For those plants which did produce flowers, the mean age of first flowering was 2.30 years ( \pm 1SE $0.072, n=197)$. If an individual lived long enough it generally produced an increasing number of flowers each year until it was 5 years of age, although very old plants had fewer flowers (see column $m_{x_{1}}$ Table 2 ). There was a strong positive relationship between flower number and plant area $\left(r^{2}=0.71, n=1278, \mathrm{p}<0.001\right)$ (Fig. 5). One individual grew as many as 123 flowers over its entire lifespan (8 years), with 50 of these produced when it was 5 years old and had reached its maximum size of $17.5 \mathrm{~cm}^{2}$. Thus, the most fecund plants were a small number of large, long-lived individuals, with the vast majority being diminutive and developing few or no flowers. 


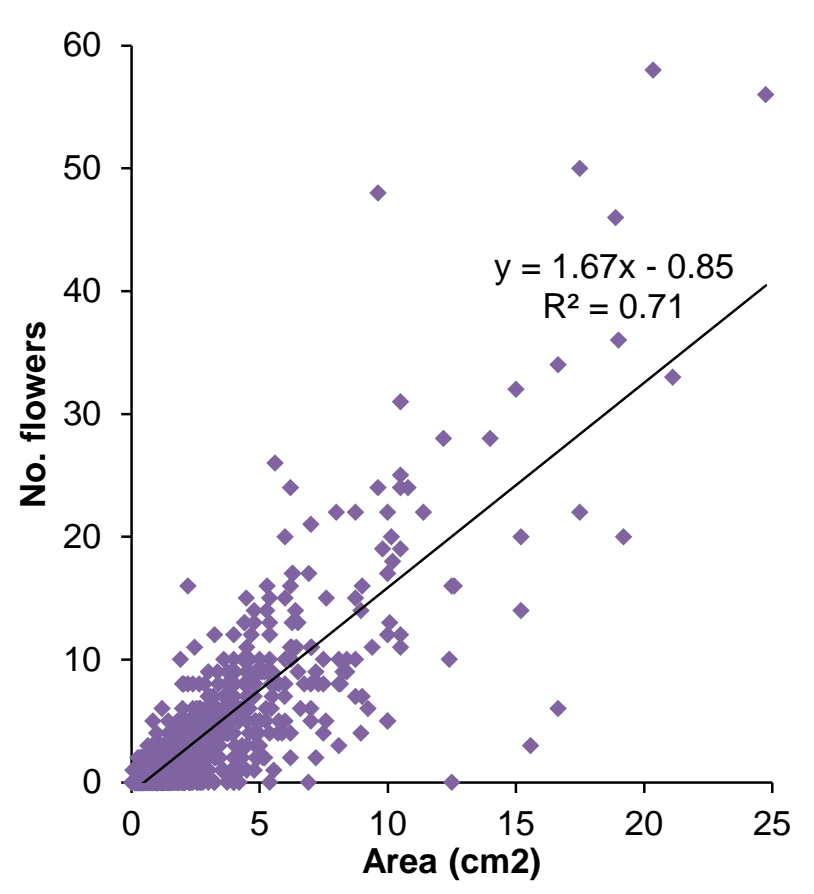

Figure 5. Relationship between the number of flowers produced by Sagina nivalis and plant size.

Full population surveys (1996 \& 2014)

In total, 3714 plants were counted across Ben Lawers in 1996 but only 1848 in 2014 , which represents a decline of $50.24 \%$ after 18 years. Of the 37 individual colonies which were surveyed, $19(51.3 \%)$ were extinct, 12 (32.4\%) had declined significantly, two (5.4\%) were stable and only four (10.8\%) had increased.

\section{Discussion}

Long-term monitoring of individuals of Sagina nivalis within fixed plots on Ben Lawers has revealed dramatic fluctuations in the numbers over 14 years. Most of these fluctuations were associated with the physical instability of the habitat in which S. nivalis occurs, indicating that the population dynamics of the species are strongly influenced by the fragile nature of its montane environment which is highly susceptible to disturbance caused by rockfalls, trampling and flooding. Individuals in Plots 1 and 3 had significantly longer lifespans than those in the other study plots ( $P$ $<0.001$ ), and with the exception a landslip event in Plot 1 early in the study, these sites were subject to fewer observable changes (as was Plot 5). Habitat dynamism for $S$. nivalis is chiefly derived from natural, ongoing erosion of cliffs and steep slopes, combined with frost heave, rockfalls, and in some places, occasional inundation with water. When accelerated (sometimes by sheep) these geomorphological events can catastrophically reduce populations or even cause them to disappear entirely.

However, such processes maintain suitably open habitat for S. nivalis by preventing encroachment by more competitive grasses, sedges, herbs and mosses. If left undisturbed the plots tended to become overgrown with vegetation towards the end of the study which also coincided with population declines. In fact, alpine snow bed plants are sensitive to competition because a denser canopy reduces light availability (Austrheim \& Eriksson, 2001) and belowground competition may be particularly severe in nutrient-poor high mountain pioneer soils (Dullinger \& Hülber, 
2011), although this may not be so relevant at Ben Lawers. In addition, environmental disturbances can be important for creating the conditions favourable for arctic-alpine seedling establishment (Chambers, 1995).

Alternatively, the longer lifespan of the plants in Plots 1 and 3 could be related to their lower population densities, which would have reduced the level of competition between $S$. nivalis plants. Both sites also included areas of bare rock, particularly Plot 3 , which would have provided fewer niches for colonisation by $S$. nivalis or indeed other competitive species, hence the lower levels of vegetation encroachment at these locations.

The life history of the species also reflects its dynamic and unstable habitat. The majority of plants were extremely short-lived, diminutive and developed few or no flowers. Plants with short lifespans often occur in open, disturbed areas (García et al., 2007). This study also found that individuals experienced a constant chance of surviving from one age to the next throughout their lives once they passed the seedling stage. A Type-II survivorship curve could be a characteristic of alpine perennials because the extreme abiotic stresses they are subjected to maintain consistent mortality rates during all stages of their life span. Local environmental conditions can exert an important influence on the shape of a survivorship curve (Aziz \& Khan, 1993). However, the cushion-forming Silene acaulis, which can grow alongside $S$. nivalis, instead follows a characteristic Type-III survivorship curve and is much longer lived (Morris \& Doak, 1998). But it has extremely high mortality rates in the early years of life, as does $S$. nivalis during the seedling stage.

High mortality of seedlings is an important component of the selection operating in plant life cycles (Silvertown \& Dickie, 1980) and is not uncommon in arctic-alpine environments (Chambers, 1995; Forbis, 2003). For S. nivalis this may be because the seeds germinate where they drop, usually close to mature plants. This creates clusters of seedlings so dense that few plants could ever grow to maturity. The reproductive ecology of many arctic alpines, in terms of dispersal distances, vegetative spread or regeneration, seed longevity or the existence of any seed bank in the soil, is poorly known. A highly restricted seed dispersal capacity has been recorded for other snowbed species and passively dispersed alpine plants (Scherff et al., 1994). Evidence of short-range seed dispersal of S. nivalis by gravity was provided by the regeneration of the entire colony in study Plot 4 after it was wiped out by a landslip in 1983. Thus, it is conceivable that the minute seeds of $S$. nivalis are dispersed by wind or carried downhill by the flow of surface water and snowmelt. It is also possible that entire individuals or plant fragments that have been uprooted could take root elsewhere, which may explain the occasional appearance of some new adult plants within the plots.

This study found correlations between plant age, size, and the number of flowers in $S$. nivalis, with such relationships documented across a range of plant species (Silvertown, 1985; Waller, 1988; Weiner, 1988; Ollerton \& Lack, 1998; Pires et al., 2014). In fact, the neighbouring Silene acaulis also increased in cushion diameter with age (Morris \& Doak, 1998). Plant size is usually considered a predominantly environmentally influenced characteristic, determined by plant age and growing conditions (Waller, 1988; Ollerton \& Lack, 1998). Flowering performance was the only reproductive attribute that could be recorded in our field study. Unidentified and unmeasured variables may be affecting other attributes, e.g. pollination rates, seed production, fertility and germination. 


\section{Implications for conservation}

This study has indicated that a small proportion of individuals within populations of Sagina nivalis have considerably greater longevity and fecundity than the vast majority. These long-lived individuals may impart some long-term stability to the populations. It appears that maximum size and reproductive capacity is achieved by plants that live to 5 years of age. Therefore, populations may be at risk from instabilities and changes in the habitat that prevent at least some plants from reaching this age. Such threats recognised from this study and other, ongoing observations at Ben Lawers include natural and anthropogenic factors, which are not necessarily unrelated:

1. Habitat damage from natural, dynamic processes

2. Impact of human recreational activities

3. Direct impact of sheep

4. Climate change

Geomorphological processes have already been discussed above. Erosion and disturbance by hillwalking can significantly damage montane habitats (Bayfield, 1979; Bayfield et al., 1981; Thompson et al., 1987), particularly at popular hills such as Ben Lawers. Here the main walking routes at present do not coincide with $S$. nivalis habitat, and so human activity is unlikely to pose a significant threat to the overall population. Localised trampling by botanically interested visitors has been observed where the habitat is shared with several other rare or scarce species.

However, sheep trampling destroyed plants and caused a significant decline in the populations of S. nivalis at Plots 9 and 10. Its potential as a threat is also suggested by the fact that the plots with the longest mean plant lifespan, 1 and 3 , were the only inaccessible locations (as well as Plot 2, which was not included in the lifespan analysis). It is doubtful that $S$. nivalis is selectively grazed due to its low profile and any effects of dung and urine are not known. Grazing may provide some benefit for arctic-alpines by suppressing competing species and facilitating recruitment through small-scale disturbances (Austrheim \& Eriksson, 2001), although this has not yet been observed for $S$. nivalis. Nevertheless, it is generally thought that a reduction in sheep grazing in montane Britain will promote the conservation of some summit communities (Thompson et al., 1987; Thompson \& Brown, 1992). At Ben Lawers this is dependent upon the NTS acquiring heritable grazing rights currently owned by several independent farmers.

The overall pattern of population change throughout this study was a rapid increase in numbers of $S$. nivalis followed by a slower, progressive and serious decline since 1985. Furthermore, the number of plants present across the whole of Ben Lawers SSSI has halved between 1996 and 2014, with half of all colonies now extinct and a further third in significant decline (Watts, 2014). These trends, along with the association with snow that is implicit in the species name, suggest that climate change could be having a serious impact on S. nivalis in Scotland. There has been a declining trend in the number of days of snow cover at Ben Lawers between 1979 and 2003, particularly, at 900m (Trivedi et. al., 2007). This has been obvious since the beginning of the 1990s, in contrast to the initial years of the study when the plots became buried by early, autumnal snowfalls which provided months-long continuity of cover (D.K. Mardon, personal observation).

The snow cover at $1060 \mathrm{~m}$ is projected to be reduced by $21 \%$ by the 2050 s under a low greenhouse gas emissions scenario and by $32 \%$ under a high emissions scenario (Trivedi et. al., 2007). Climate change has already caused biotic 
homogenization of the Scottish uplands through an increase in generalists, such as graminoids, and a decline in specialist arctic-montane species (Ross et. al., 2012). Snow is probably critically important for $S$. nivalis because it protects alpine habitats from erosive processes such as freeze-thaw cycles and suppresses competing species by shortening the growing season (Belsky \& Moral, 1980; Björk \& Molau, 2007). This may be one reason why vegetation encroachment occurred in 9 out of 10 plots towards the end of the study. A reduction in snow duration will also allow greater access by sheep, thereby increasing grazing impacts (Austrheim \& Eriksson, 2001) and accelerating slippage and rockfalls through hoof action on soils made unstable by frost heave (D.K. Mardon, personal observation). An interaction between threats 1,3 and 4 is therefore likely (Trivedi et. al., 2008). As a result, S. nivalis may be one of the most vulnerable of all British vascular plants to climate change. Consequently, the rear edge population of this species and its associated biodiversity value and evolutionary potential is at risk. The results of this study also have implications for populations of other rare Scottish arctic-alpines residing in similar habitats, for example Minuartia rubella and Saxifraga cernua, as it is likely that they will likewise be subjected to the threats imposed on S. nivalis.

Monitoring is essential for detecting trends in montane communities and for developing conservation policies, particularly in the face of climate change (Trivedi et. al., 2008). The documentation of the distribution and abundance of the rare plant species at Ben Lawers has been mostly carried out by employees of the NTS, the owner of the NNR as currently designated. It is unlikely that landowners other than conservation bodies would undertake the time-consuming, detailed observations needed to understand and conserve such species. Of the 1,848 S. nivalis plants recorded in 2014, $78 \%$ were on NTS land. Therefore, the Trust has a unique responsibility for the future of the species in Scotland. We believe that the ability to enhance and promote understanding of it, as well as others in a similar but less extreme situation, will depend on the long-term continuity of resident staff with an ecological bias at Ben Lawers.

\section{Acknowledgments}

We are grateful to Sandy Payne for help in establishing the project at the end of his 1981 survey, and for many constructive comments on developing drafts of this paper. The 1996 population survey was carried out by Andrew MacGregor. We also thank Gordon Miller and John Holland for helpful comments and advice. Help with fieldwork from numerous volunteers and colleagues shortened some very long shifts on the hill. We are also grateful to the National Trust for Scotland for continuing support to complete this project. The conservation work of the Trust was supported by The Nature Conservancy Council, to 1991, and Scottish Natural Heritage in later years.

\section{References}

Austrheim, G. \& Eriksson, O. 2001. Plant species diversity and grazing in the Scandinavian mountains - patterns and processes at different spatial scales. Ecography, 24: 683-695. https://doi.org/10.1111/j.1600-0587.2001.tb00530.x

Aziz, S. \& Khan, M.A. 1993. Survivorship patterns of some desert plants. Pakistan Journal of Botany, 25(1): 67-72. http://www.halophyte.org/pdfs/drkhan pdfs/25.pdf 
Bayfield, N.G. 1979. Recovery of four montane heath communities on Cairngorm, Scotland, from disturbance by trampling. Biological Conservation, 15(3): 165179. https://doi.org/10.1016/0006-3207(79)90038-7

Bayfield, N.G., Urquhart, U.H. \& Cooper, S.M. 1981. Susceptibility of four species of Cladonia to disturbance by trampling in the Cairngorm Mountains, Scotland. Journal of Applied Ecology, 18(1): 303-310. https://doi.org/10.2307/2402497

Begon, M., Harper, J.L. \& Townsend, C.R. 1996. Ecology: Individuals, populations and communities. $3^{\text {rd }}$ ed. Oxford: Blackwell.

Belsky, J. \& del Moral, R. 1980. Ecology of an alpine-subalpine meadow complex in the Olympic Mountains, Washington. Canadian Journal of Botany, 60: 779-788. https://doi.org/10.1139/b82-101

Benum, P. 1958. The flora of Troms Fylke. A floristic and phytogeographical survey of the vascular flora of Troms Fylke in northern Norway. Tromsø: Tromsø Museum.

Björk, R.G. \& Molau, U. 2007. Ecology of alpine snowbeds and the impact of global change. Arctic, Antarctic, and Alpine Research, 39(1): 34-43. https://doi.org/10.1657/1523-0430(2007)39[34:EOASAT]2.0.CO;2

Chambers, J.C. 1995. Disturbance, life history strategies, and seed fates in alpine herbfield communities. American Journal of Botany, 82(3): 421-433. https://doi.org/10.1002/j.1537-2197.1995.tb12647.x

Clapham, A.R., Tutin, T.G. \& Warburg, E.F. 1962. Flora of the British Is/es. Cambridge: Cambridge University Press.

Dullinger, S. \& Hülber, K. 2011. Experimental evaluation of seed limitation in alpine snowbed plants. PLoS ONE, 6(6), e21537. https://doi.org/10.1371/journal.pone.0021537

Evans, D. 1982. Distribution and soil preferences of Carex microglochin and Sagina intermedia in the Ben Lawers area. B.Sc. (Hons) thesis, University of Stirling.

Forbis, T.A. 2003. Seedling demography in an alpine ecosystem. American Journal of Botany, 90(8): 1197-1206. https://doi.org/10.3732/ajb.90.8.1197

García, M.B., Xavier Picó, F. \& Ehrlén, J. 2007. Life span correlates with population dynamics in perennial herbaceous plants. American Journal of Botany, 95(2): 258-262. https://doi.org/10.3732/ajb.95.2.258

Geddes, C. \& Miller, G.R. 2010. Long-term changes in the size of an Alpine Gentian, Gentiana nivalis L., population in Scotland. Watsonia, 28: 65-73. https://www.researchgate.net/publication/279203295/download

Hampe, A. \& Petit, R.J. 2005. Conserving biodiversity under climate change: the rear edge matters. Ecology letters, 8: 461-467. https://doi.org/10.1111/j.14610248.2005.00739.x

Lauenroth, W. \& Adler, P. 2008. Demography of perennial grassland plants: survival, life expectancy and life span. Journal of Ecology, 96: 1023-1032. https://doi.org/10.1111/j.1365-2745.2008.01415.x

Legg, C., Cowie, N. \& Sydes, C. 1997. The importance of regeneration studies to the successful conservation management of Scottish rare plants. Botanical Journal of Scotland, 49(2): 425-432. https://doi.org/10.1080/03746609708684887

MacGregor, A. 1996. A review of the Status of the Snow Pearlwort Sagina nivalis on the Ben Lawers and Tarmachan Ranges. National Trust for Scotland report. Located at: National Trust for Scotland, Lynedoch, Killin, Scotland.

Morris, W.F. \& Doak, D.F. 1998. Life history of the long-lived Gynodioecious cushion plant Silene acaulis (Caryophyllaceae), inferred from sized-based population 
projection matrices. American Journal of Botany, 85(6): 784-793.

https://doi.org/10.2307/2446413

Milne, J.A. \& Hartley, S.E. 2001. Upland plant communities - sensitivity to change. Catena, 42: 333-343. https://doi.org/10.1016/S0341-8162(00)00145-4

Ollerton, J. \& Lack, A. 1998. Relationships between flowering phenology, plant size and reproductive success in Lotus corniculatus (Fabaceae). Plant Ecology, 139: 35-47. https://doi.org/10.1139/B07-135

Payne, A.G. 1981. The status of Sagina intermedia in Great Britain. National Trust for Scotland report. Located at: National Trust for Scotland, Lynedoch, Killin, Scotland.

Pires, J.P.D.A., Silva, A.G.D. \& Freitas, L. 2014. Plant size, flowering synchrony and edge effects: what, how and where they affect the reproductive success of a Neotropical tree species. Austral Ecology, 39: 328-336. https://doi.org/10.1111/aec.12082

Provan, J. \& Maggs, C.A. 2011. Unique genetic variation at a species' rear edge is under threat from global climate change. Proceedings of the Royal Society B: Biological Sciences, 279: 39-47. https://doi.org/10.1098/rspb.2011.0536

Raven, J., \& Walters, M. 1956. Mountain flowers. London: Collins.

Rehm, E.M., Olivas, P., Stroud, J. \& Feeley, K.J. 2015. Losing your edge: climate change and the conservation value of range-edge populations. Ecology and evolution, 5(19): 4315-4326. https://doi.org/10.1002/ece3.1645

Ross, L.C., Woodin, S.J., Hester, A.J., Thompson, D.B.A. \& Birks, J.B. 2012. Biotic homogenization of upland vegetation: patterns and drivers at multiple spatial scales over five decades. Journal of Vegetation Science, 23(4): 755-770. https://doi.org/10.1111/j.1654-1103.2012.01390.x

Ross, L. 2015. Climate change impacts on the vegetation of Ben Lawers. Scottish Natural Heritage Commissioned Report No. 879. https://doi.org/10.13140/RG.2.1.1908.0801

Scherff, E.J., Galen, C. \& Stanton, M.L. 1994. Seed dispersal, seedling survival and habitat affinity in a snowbed plant: limits to the distribution of the snow buttercup, Ranunculus adoneus. Oikos, 69(3): 405-413. https://doi.org/10.2307/3545853

Silvertown, J. 1985. Survival, fecundity and growth of wild cucumber, Echiocystis lobata. Journal of Ecology, 73(3): 841-849. https://doi.org/10.2307/2260151

Silvertown, J. \& Dickie, J. 1980. Seedling survivorship in natural populations of nine perennial chalk grassland plants. New Phytologist, 88: 55-558. https://doi.org/10.1111/j.1469-8137.1981.tb04099.x

Stace, C.A. 2010. New flora of the British Isles $3^{\text {rd }}$ ed. Cambridge: Cambridge University Press.

Sydes C. 2008. Can we protect threatened Scottish arctic-alpine higher plants? Plant Ecology \& Diversity, 1(2): 339-349. https://doi.org/10.1080/17550870802349179

Thompson, D.B.A. \& Brown, A. 1992. Biodiversity in montane Britain: habitat variation, vegetation diversity and some objectives for conservation. Biodiversity and Conservation, 1: 179-208. https://doi.org/10.1007/BF00695915

Thompson, D.B.A., Galbraith, H. \& Horsfield, D. 1987. Ecology and resources of Britain's mountain plateaux: land use conflicts and impacts. In: Bell, M. \& Bunce, R.G.H. Agriculture and Conservation in the Hills and Uplands. ITE Symposium no.23. http://nora.nerc.ac.uk/id/eprint/4992/1/23.pdf 
Trivedi, M.R., Browne, M.K., Berry, P.M., Dawson, T.P. \& Morecroft, M.D. 2007. Projecting climate change impacts on mountain snow cover in central Scotland from historical patterns. Arctic, Antarctic and Alpine Research, 39(3): 488-499. https://www.tandfonline.com/doi/abs/10.1657/1523-0430\%2806006\%29\%5BTRIVEDI\%5D2.0.CO\%3B2

Trivedi, M.R., Morecroft, M.D., Berry, P.M. \& Dawson, T.P. 2008. Potential effects of climate change on plant communities in three montane nature reserves in Scotland, UK. Biological Conservation, 14(1): 1665-1674. https://doi.org/10.1016/j.biocon.2008.04.008

Waller, D.M. 1988. Plant morphology and reproduction. In: Lovett-Doust, J. \& Lovett-Doust, L., eds. Plant reproductive ecology: patterns and strategies $\mathrm{p}$. 203-227. Oxford: Oxford University Press. https://www.researchgate.net/profile/Jon Lovettdoust/publication/44544439 Plant reproductive ecology patterns and strategi es Edited by Jon Lovett Doust and Lesley Lovett Doust/links/552ea7120cf2 acd38cbbd4b9/Plant-reproductive-ecology-patterns-and-strategies-Edited-byJon-Lovett-Doust-and-Lesley-Lovett-Doust.pdf

Watts, S.H. 2014. A census of snow pearlwort Sagina nivalis on Ben Lawers SSSI 2014. National Trust for Scotland report. Located at: National Trust for Scotland, Lynedoch, Killin, Scotland.

Weiner, J. 1988. The influence of competition on plant reproduction. In: LovettDoust, J. \& Lovett-Doust, L., eds. Plant reproductive ecology: patterns and strategies p. 228-245. Oxford: Oxford University Press. https://www.researchgate.net/profile/Jon Lovettdoust/publication/44544439 Plant reproductive ecology patterns and strategi es Edited by Jon Lovett Doust and Lesley Lovett Doust/links/552ea7120cf2 acd38cbbd4b9/Plant-reproductive-ecology-patterns-and-strategies-Edited-byJon-Lovett-Doust-and-Lesley-Lovett-Doust.pdf

Wigginton, M.J. 1999. British red data books 1 Vascular plants $3^{\text {rd }}$ ed. Peterborough: Joint Nature Conservation Committee.

Copyright retained by author(s). Published by BSBI under the terms of the Creative Commons Attribution 4.0 International Public License. 